his principles, an impressive piece of apparatus which aroused considerable interest. His procedure is perhaps only admissible as a 'physical method' by virtue of the fact that the extensive chemistry involved in the analysis is very unobtrusively and automatically performed. In introducing his paper, Mr. Gooderham said that given a series of accurate gas meters which do not appreciably absorb gas or cause loss of pressure, the simplest form of gas analysis can be obtained by passing gas through a meter, a reagent which removes one constituent completely, another meter, another reagent and so on. The soap-film meter, which he has described in earlier papers ${ }^{4}$, is ideal for this purpose. The apparatus demonstrated was arranged for the analysis of coal gas; this operation only took a minute or so to carry out, and the percentage analysis of a sample could be read directly from the meters. This was done by allowing the initial intake meter to move up 100 divisions, and then noting the change in each of the other meters, which represented the gas volume after successive constituents had been removed. Conventional reagents were used for absorption; but it was necessary to design the absorption pipettes so that only a very small back-pressure was developed.

Since the method is a dynamic one, a certain minimum passage of gas through the apparatus is necessary before reproducible final analyses were obtained. Several speakers in the discussion referred to this point, and $\mathrm{Mr}$. Gooderham said that $1-1 \frac{1}{2}$ litres of gas is usually sufficient to complete a full analysis with several repeats, and the sweeping-out operation, which normally took half an hour or so, could be speeded up if required. He also stated, in reply to other questions, that the accuracy of the apparatus is $0 \cdot 2$ per cent on each constituent, but that it might be possible to design for a greater sensitivity than this. Apparatus for the determination of carbon dioxide, oxygen and carbon monoxide in waste gases has also been made and used. It is preferable to use a special acidic soap solution for the meters.

The meeting was a pleasant and profitable one. It is expected that the papers which were read will shortly be reproduced in full in The Analyst.

1 Prescott, C. H., and Morrison, J., Indust. Eng. Chem. (Anal. Ed.), 11, 230 (1939)

2 Campbell, N. R., Proc. Phys. Soc., 33, 287 (1921).

Podbielniak, W. J., Indust. Eng. Chem. (Anal. Ed.), 3, 177 (1931);

5, (1933) 119; 5, 172 (1933); 13, 639 (1941).

- Gooderham, W. J., J. Soc. Chem. Ind., 59, 1 (1940); 63, 351 (1944).

\section{CONGRESS OF THE \\ INTERNATIONAL ASSOCIATION FOR THE PROTECTION OF INDUSTRIAL PROPERTY}

$\mathrm{T}$

HE Congress of the International Association

for the Protection of Industrial Property (sometimes affectionately termed 'Pip') was held recently at The Hague at the invitation of the Netherlands Group of the Association. This Congress had been originally fixed for 1940 .

The Association is an informal body of industrialists, patent agents, barristers and solicitors who are directly interested in questions relating to inventions, designs, trade marks and copyright. The expression 'industrial property' is a convenient portmanteau phrase for describing commercial rights connected with international trade and industry. It was largely as a result of the endeavours of the Association that the International Convention of 1883 was signed by the representatives of forty countries. The Convention agreement is not binding upon the domestic legislation of the countries adhering to it. It is, in effect, a code of conduct to facilitate international trade, and one of its main objects is to prevent all kinds of unfair trading.

The Association maintains a constant watch over international relationships in these matters, and the Congress at The Hague was an outstanding example of its activities. There were about four hundred delegates from most of the countries of the world except the U.S.S.R., Germany and Japan. The British group comprised about fifty delegates including seven counsel, and the British point of view was expressed with commendable clarity.

On the opening day of the Congress the president of the British Group, Mr. Lionel F. Heald, K.C., submitted a proposal that any question relating to the interpretation of the language of the International Convention should be referred to the International Court of Justice at The Hague. After a lively and well-informed discussion in which the great majority of the countries represented took part, the president of the Association (Senator Marcel Plaisant of France) was able to announce that the proposition had been carried unanimously.

Another interesting matter which caused much discussion concerned the translation of trade marks from one language to another. When goods have been sold under a 'trade name' which is a word in the vernacular of one of the countries, it may happen that a trader in another country may attempt to market similar goods in that foreign country under the name which is a translation of this word. The British delegation urged that if goods were registered abroad under a word in the language of origin of the goods, then that registration should cover the translation of the word in the vernacular of the foreign country. Although this view was not accepted by the Conference as a whole, it was unanimously agreed that a word and its translations in other countries could be registered at one and the same time, and that this step would be helpful in avoiding unfair trading.

By the Convention of 1883 , an International Office of the Association was established at Berne and was placed under the authority of the Swiss Government. This Office centralizes information of every kind relating to the protection of industrial property, and pablishes it. To facilitate this important work, it was resolved that countries adhering to the Convention should communicate to the Berne office all acts and statutory rules and orders relating to industrial property arising in the course of their domestic legislation. If any country failed to carry out the reciprocal commitments contained in the Convention, it was felt that the International Office at Berne should have powers to bring this fact to the attention of the Government of the country in question. The International Association should be given powers to formulate officially any opinion which it might be asked to give by the Government of any adherent country concerning its interpretation of the Convention.

One resolution concerned a modification of the procedure for priority rights in other countries in respect of an application for a patent or for the registration of a utility model, industrial design or trade mark in one of the Convention countries. 
Two other resolutions concerned the international registration of trade marks. Another resolution provided that the validity of a 'patent of addition' should not necessarily be affected should the substantive patent be declared invalid or be revoked. In the light of the increase in modern scientific research, whether sponsored by Governments, by universities, or by firms, it is increasingly desirable that its practical or industrial applications should not only be carefully studied from a national aspect but also from an international aspect. The representatives at this Congress appreciated that if international trade is to be increased it is essential that harmony should be achieved between the laws of different countries relating to industrial property. The discussions at the Conference were sincere attempts to achieve this end, and the Conference assumed a further world-wide significance in view of the formation of the Economic Council of the United Nations Organisation.

\section{SIXTH INTERNATIONAL CONGRESS OF EXPERIMENTAL CYTOLOGY}

$\mathrm{T}$ HE Sixth International Congress of Experimental Cytology met in Stockholm during July 10-17; some four hundred members from twenty-three countries attended. It was of outstanding interest in several ways. But for the War, this Sixth Congress would have met in 1940 at Stockholm, so the international ties in this branch of science were here appropriately reformed. Secondly, the official scope of 'experimental cytology' has now been broadened. Under the late Prof. Rhoda Erdmann, research based on the tissue-eulture technique had taken a central position in pre-war meetings. Now, with the shift of the centre of gravity towards sub-microscopical biology, topies at this Congress ranged in ascending orders of magnitude from that of the large molecule to the whole organ.

To cover so wide a field, it was necessary in part to organise the Congress in separate sections, and here great tribute is due to the organising committee, and particularly to the general secretary, Dr. H. Hyden, for the admirable way in which the programme was arranged and carried out. The main sessions of the Congress generally took the form of symposia, at which recent work in each field was presented, mainly by the leading figures therein from New and old Worlds.

It was clear that there had disappeared one of the cleavages in pre-war biology, namely, that between the disciplines of biochemistry and microscopical investigation. The focal interest in the biological significance of the nucleic acids and the development of the technique of analysis by differential centrifugation have effectively contributed to bridge this gap.

The freedom with which different techniques are now being used in particular fields was well illustrated both by the papers on muscle proteins and in the microbiological sections. The results obtained by the different methods are by no means yet in complete agreement; but the interplay of the different points of view both in the papers and in discussion was of great interest.

The contribution of Swedish men of science to the success of the Congress was at least of equal importance to that of the membership. Laboratories in
Stockholm, Uppsala and elsewhere were freely open to visitors. Although Prof. Caspersson's new institute is not yet ready, there was a superb demonstration in the form of a series of panels which adequately expounded the work of his school. It was an experience deep with meaning to see the progress in science of a small country that has escaped the direct wastage of war.

The social side of the Congress was further memorable. Members were the guests of the city of Stockholm in the magnificent town hall on the shore of Lake Malar, and also, some days later, of the Biochemical Industrial Concern of Kärnbolaget.

The Congress concluded with a business session which refounded an International Society for Cell Biology, at which plans were announced for new international journals, of which one for cytological topics is to be edited from Sweden.

\section{ORGANISATION OF THE CAPILLARY CIRCULATION}

$\mathrm{W}$ HILE it is obvious that the capillary circulation is subject to local physiological control, there is much difference of opinion as to how this is achieved. In particular, it is still undecided whether or not the capillaries exhibit independent contractility and, if so, whether this is due to the presence of special perivascular contractile cells. Hitherto the capillary bed has been regarded as a network of capillaries of uniform structure fed by artierioles and drained by venules. Recent work, however, particularly by R. Chambers and B. W. Zwoifach, has shown that the capillary bed comprises several different types of vessels which can now be separately defined, and each of which plays a particular part in the total functional organisation of the capillary bed.

Chambers and $Z$ weifach have recently summarized their findings (Ann. New York Acad. Sci., 46, 683 ; 1946). Their observations were principally made on the rat's mesentery; but a similar pattern was found in subcutaneous tissue and skeletal muscle. They find that each arteriole is connected to a venule by one rather long straight vessel, the 'central channel' or 'arteriovenous channel' (not to be confused with arteriovenous anastomoses). The true capillaries arise as lateral offshoots from the proximal part of the central channel, form anastomosing networks and drain into the distal part of the central channel and also directly into venules. The proximal part of the central channel is called the 'metarteriole'; it is provided with muscle, and together with the arteriole is responsible for vasomotor control of the total blood flow through the capillary bed. The distal part of the central channel is non-muscular. Abrupt lateral branches from the metarteriole lead to the capillary networks. These lateral branches are muscular for a short distance. The muscular part is termed the 'precapillary' and acts as a sphincter controlling the admission of blood to the network of true capillaries beyond.

While the tissues are in a resting state there is relative ischæmia, the precapillary sphincters are closed and the blood flow is confined to the central channel. During tissue activity there is hyperæmia, the sphincters are open and blood flows through the whole capillary network. The true capillaries seem to exhibit no active vasomotor changes, their walls contain no adventitial contractile cells, neither do 